\title{
Influence of Advanced Technologies for Continuing Medical Education
}

\author{
Na Wang \\ Department of Anesthesiology \\ The First Hospital of Jilin University \\ Changchun, China \\ wangna080613@163.com
}

\author{
Corresponding author: Jinguo Wang* \\ Department of Urology \\ The First Hospital of Jilin University \\ Changchun, China \\ wangjinguolily@163.com
}

\begin{abstract}
Education is the success of developing knowledge economy. In the era of fast-developing economy, the development of medical education must be a little faster than that of the economy. We suggest adjusting the medical education structure and strengthening the continuing medical education. Development of continuing medicine education is building a system of lifelong medical education. Deepening the reform of education and actively developing private education are two methods to tell the learner how to master and use information to guide medical workers, to establish innovative consciousness, to disseminate medical technology ethics and to improve the comprehensive quality of medical workers.
\end{abstract}

Keywords-advanced technology; implication; continuing education; medicine

\section{INTRODUCTION}

The essence of knowledge economy is knowledge innovation which makes knowledge become the main factor of production. Knowledge as one of the core of elements is the human resources that can be represented. Low quality human resources can be a heavy burden for underdeveloped countries and regions [1]. Only through scientific development, the human resources can have the modern quality, master the skill. High quality human resources are the most important resources of the development of a country or a region. The knowledge economy is the talent of economy, and the cultivation of talent depends on the development of education and the full play of its function [2].

Mastery of knowledge is the key to a promoting future. Education is the success of developing knowledge economy. According to the current advanced medical education and the requirement for the sustainable development of social economy it still exists some contradictions [3]. The reform of medical education must start with a new idea and a new method moving towards a new development goal.

\section{IMPORTANCE OF NEW TECHNOLOGY AND CONTINUING} EDUCATION

\section{A. New Technology}

The modern science and technology develop faster and faster, with the emergence of new technologies which update speed faster and faster [4]. The transformation cycles of scientific and technological achievements into real productive forces are getting shorter. A lifelong career has become the past and finished. At past, a person no matter learn how much modern professional knowledge in colleges and universities. The professional knowledge will appear out of date in several years [5]. Therefore, secondary and after-school education should be promoted to be adapted to the sustainable development of medicine. Only by this method, the medical talents can be found invincible in the fierce competition. There are other forms of education in medicine after school. You can go back to medical school [6]. There are also corporate research institutions that train learners. At the same time, with the popularization of the Internet, a school that can send education to thousands of students in their families.

Virtual schools came into being. It not only can meet the demand of people who accept the lifelong medical education, but also can solve the dispersed disadvantages of traditional medical education resources. It achieves the recombination of medical education resources and the society [7]. At present, the development of adult education in medicine in China is becoming more and more mature. The number of students taking the adult college entrance examination and self-study examination is increasing year by year. Recently, the state has issued new regulations on college enrollment, which will make it more favorable for the development of education in medicine.

\section{B. Continuing Medical Education}

New medical technologies speed up the industrialization process, because the demand for survival and the health of the human has the characteristics of the continuous deepening. People always try to use the most advanced technologies, concepts and means to improve diagnosis, treatment system and equipment [8]. This is a medical technology to speed up the industrialization process associated with market demand. Because of medical technology has the characteristics of high returns, which induced the through tend to promote priority of the development of medical technology to promote the development of national economy; it is the power source of the new medical technology to speed up the industrialization process [9]. It is due to the fundamental interests of the human survival and health which are the attention of the fundamental cause of medical science and technology industry. It becomes the various countries' demand and economic demand of persistent sunrise industry which is characterized by new medical technology. It speeds up the industrialization process because of the induced factors. 


\section{EXPLORATION OF CONTINUING MEDICAL EDUCATION}

Medical professionalism is used to emphasize the collective sense of responsibility and virtue individual behavior. It belongs to the category of personal moral accomplishment and social ethics which have the function of guiding direction of medical personnel behavior. In this sense, the training of medical professional spirit is to set up the correct life value orientation of the problem [10]. The market economy is more self-life value orientated and advocating pragmatic than the traditional medical professional spirit, so it is necessary to have the life value orientation of medical professionalism under the condition of market economy. It has a new understanding.

At present, governments at all levels and relevant departments of rural health care focus on the construction of rural healthcare system, as well as the improvement of village doctor education system. Village doctor education implementation of effective management is to ensure that the education of rural doctors still is an important factor of success. The perfection of education management policy and implementing of the policy at all levels can't be ignored.

\section{A. Emphasis on Self-worth}

Under the condition of market economy, the individual's value is prominent, emphasizing the value of self. The value subject is shifted from the whole standard to the individual standard. The medical profession is facing a serious challenge to the medical profession. It is more and more acute in the medical field. A person who can realize self-value can establish themselves in society position and better play with their enthusiasm, initiative and creativity [11]. He can develop themselves in various aspects and strive for perfection in our business. But the value of the subject standard deviates to individual standard in the process, because the whole people pay attention to the independence, autonomy, striving to improve at the same time. The spirit of collectivism, indifference to each other, spirit of helping and supporting each other, social responsibility and historical mission in the value idea are more and more in a subordinate position. Some people are even extremely individual, self-interested and self-centered. Medical professional spirit emphasizes and is guided by the conduct of basic medical professional activities, such as treating colleagues, medical research, et al [12]. To summon medical personnel sense of responsibility to the society is the scientific sense of pride. Under the condition of market economy, individual self - standard value is prominent, and the whole standard value of medical professional spirit is difficult to establish.

\section{B. Improvement of the Personnel Quality}

Talents are the carrier of knowledge resources, the lifeblood of economy and the commanding height of competition. In order to meet the requirement of high-level medical talents in knowledge economy age, the process of continuing medical education should base on the relevant policies and regulations of the state, the overall arrangement and planning of talents construction. In terms of cultivating targets and objects, it is necessary to cultivate and create the high-level innovative talents suitable for the unit according to the actual or regional health development needs of the unit. Continuing medical education is an important approach to cultivate high-level and high-quality medical talents, so it must carry on the thought idea, talent training goal and the transformation of the teaching contents and methods to produce innovative medical talents with high qualities.

\section{How to Master and Use Information}

With the construction of the information platform, the information storage of scientific research is already networked and globalized. It will become more and more common to use computer network for data exchange and timely communication. In many areas, particularly interdisciplinary research, information has a considerable degree of possession, control and processing capacity. The globalization of the means of information communication will have a profound impact on scientific research [13]. The medical association or relevant units should create conditions for medical workers to obtain information of the same subject or related subjects at the shortest time and the fastest speed to improve the efficiency of research.

In order to develop medical worker's ability to grasp and use information, the content of the continuing medical education to retrieve knowledge training includes medical, pharmaceutical, namely network system application in the field of medicine. It also includes the Internet applications in medicine, important medical pharmaceutical platform, the application of the Internet, medical CD retrieval and so on. It makes medical workers master the use of information network and improve the ability of master modern information. It makes them get the latest knowledge from the vast medical information. In this age of informationization, if we cannot master modern information skills, we will not be able to carry out scientific research effectively. Facing the challenges of the information age, it is needed to continuously strengthen the continuing education work, in order to improve the masses of medical workers to master the ability of information and become the leader of medical science and technology. Therefore, they can master scientific research and initiative, look for the right breakthrough point to speed up the process of scientific research, with a small amount of input for the success of output. It improves the level of the development and application of scientific research achievements in the fierce competition.

\section{Establishment of a sense of innovation}

With the progress of society, scientific and technological innovation has become the main theme of the development of these times. The construction of scientific and technological innovation research group has received more and more attention [9]. As an important part of scientific and technological talents, medical talents have a high degree of innovation ability. The development of the hospital depends on the talent who need to have the ability of science and technology innovation ability. To construct practical system to cultivate scientific, reasonable and technological innovation ability of medical talent. To establish comprehensive evaluation system to discover and cultivate a strong innovative ability of medical talents. Upgrading of the technological innovation of the hospital has important practical significance.

The development of medical science depends on the continuous improvement of medical knowledge and the 
continuous growth of medical talents with innovative ability [14]. The cultivation and development of innovative medical talents is the holy mission of education for medicine and the profound proposition that education needs to be carefully parsed. Based on the understanding of the core elements and forming mechanism of medical innovation ability, this thesis is put forward in the medical education community to build a medical science curriculum group to promote the innovation ability of doctors. The doctors with their mastery level of scientific research and the medical innovation ability understand the demand of the present situation. The medical staff and doctors have medical methodology knowledge. Medical institutions have medical methodology course. From clear theoretical methodology of medicine, the concept of medical methodology courses includes different subjects which have different subject characteristics. The curriculum builds a group of medical methodology course and reveals inner relations between medical curriculum system and teaching methodology course. It also demonstrates medicine form and operation mechanism.

\section{CONCLUSION}

The rapid development of market economy has brought changes of people's values and health consciousness, especially the establishment of new medical model. It raises new challenges and more rational demands for medicine. A lot of new ethical problems gradually appear in medical practice. At the same time, the nature of medical values takes the great threat in worldwide delivery system of medical service. We need to think deeply about the nature of the medicine and values. The Chinese and western national medical professionals face more and more the same dilemma.

The wave of knowledge economy makes people more and more clearly realized that knowledge is the important resources in the social and economic development. It improves the drives of the productivity and economic growth and gradually becomes the first elements in factors of production. The continuing medical education which is training on human health and economic development is a necessary avenue and plays an important role in medical innovation for talented persons. New medical technology is one of the key factors to improve human survival and health. This paper studies the characteristics of new technology of the knowledge economy era and expounds the connotation of the continuing medical education, so as to provide some suggestions for strengthening continuing medical education.

\section{REFERENCES}

[1] Amy BM Tsui, Doris YK. Law. Learning as boundary-crossing in school-university partnership[J]. Teaching and Teacher Education. 2006 (8)

[2] R Owston. Blended Teacher Professional Development: A Synthesis of Three Program Evaluations. The Internet and Higher Education. 2008

[3] Pfaffenberger A. Critical Issues in Therapy Outcome Research. Journal of Humanistic Psychology. 2006

[4] Slife BD, Lambert M. Theoretical challenges to therapy practice and research: The constraint of naturalism. Bergin and Garfield's handbook of psychotherapy and behavior change. 2004

[5] Gergen KJ. Psychological science in a postmodern context. American Psychologist. 2001

[6] King KP. Identifying success in online teacher education and professional development. The Internet and Higher Education. 2002

[7] Klaus Winter. School Autonomy and the Role of the State: some reflections on the current school educational system in Germany. European Journal. 2000

[8] The Secretary of State for Education and Skills. Further Education White Paper: Raising Skills, Improving Life Chance. 2006

[9] Capterra. The Top 20 Most Popular LMS Software. http://www.capterra.com/learning-managementsystemsoftware/\#infographic. 2015

[10] Go Globe. Smartphone Usage in China-Statistics and Trends[Infographic]. http://www.go-globe.com/blog/smartphone-usagein-china/. 2013

[11] Rheingold Howard. The Virtual Community: Homesteading on the Electronic Frontier. 1993

[12] European Union. Council Conclusions of 12 May 2009 on a Strategic Framework for European Cooperation in Education and Training (ET 2020) (2009/C 119/02). http://www.cedefop.europa.eu/EN/Files/ET2020.pdf .

[13] U.S. Department of Education. Strategic Plan: Fiscal Years2011-2014. http://www2.ed.gov/about/reports/strat/plan2011-14/plan-2011.pdf

[14] Wikipedia Moodle. https://en.wikipedia.org/wiki/MOODLE. 2015 